\title{
Trans-Aconitic acid, glucosylflavones and hydroxycinnamoyltartaric acids from the leaves of Echinodorus grandiflorus ssp. aureus, a Brazilian medicinal plant
}

\author{
Miriam Schnitzler, Frank Petereit, Adolf Nahrstedt* \\ Institute of Pharmaceutical Biology and Phytochemistry, Westfaelische Wilhelms-University Muenster, Hittorfstr, \\ 56, 48149, Muenster, Germany
}

\begin{abstract}
RESUMO: “Ácido trans-aconítico, glicosilflavonas e ácido hidoxitartárico das folhas de Echinodorus grandiflorus ssp. aureus, uma planta medicinal brasileira”. As folhas de Echinodorus grandiflorus são tradicionalmente utilizadas no Brasil devido as suas atividades diuréticas e antireumáticas. Com a finalidade de obter mais informações acerca de seus constituintes fenólicos, um extrato etanólico das folhas foi fracionado. Foram isolados cinco glicosilflavonas, cinco ácidos hidroxicinamoiltartáricos e o ácido trans-aconítico e suas estruturas foram identificadas através de dados de RMN e CLAE quiral. A determinação quantitativa dos compostos 1 - 11 através de HPLC indicou o ácido cafeoilferuloiltartárico com $0,13 \%$ como o principal representante dos ácidos hidroxicinamoiltartáricos e a swertiajaponina com $0,31 \%$ das glicosilflavonas; a quantidade de ácido trans-aconítico no material investigado foi de $0.98 \%$.
\end{abstract}

Unitermos: Echinodorus grandiflorus ssp. aureus, Alismataceae, glicosilflavonas, ácido hidroxicinamoiltartárico, ácido trans-aconítico.

\begin{abstract}
The leaves of Echinodorus grandiflorus are used traditionally in Brazil for their diuretic and antirheumatic activities. In order to obtain more information about its phenolic constituents, an ethanol leaf extract was fractionated. Five glucosylflavones, five hydroxycinnamoyltartaric acids and trans-aconitic acid were isolated and their structures identified by NMR data and chiral HPLC. Quantitative determination of compounds 1 - 11 by HPLC indicated caffeoylferuloyltartaric acid with $0.13 \%$ as the main representative of the hydroxycinnamoyltartaric acids and swertiajaponin with $0.31 \%$ of the glucosylflavones; the content of trans-aconitic acid in the investigated material was $0.98 \%$.
\end{abstract}

Keywords: Echinodorus grandiflorus ssp. aureus, Alismataceae, glucosylflavones, hydroxycinnamoyltartaric acids, trans-aconitic acid.

\section{INTRODUCTION}

Echinodorus grandiflorus ssp. aureus (Fassett) R. R. Haynes \& Holm. Niels. (Alismataceae), is a perennial plant, generally found in canals, marshes and at lake shores in the southeast of Brazil. The leaves are used in traditional Brazilian medicine for their diuretic and antirheumatic properties (Tanaka et al., 1997; Agra et al., 2007). Recently, a methanol extract of E. grandiflorus was found to have antimicrobial, analgesic and antiinflammatory activity (De Souza et al., 2004; Dutra et al., 2006). Unpublished data by Cechinel Filho (Univali, Itajai-SC, Brazil) identified caffeic acid, ß-sitosterol, and the flavones swertisin and swertiajaponin as constituents. The presence of the cembrane diterpenes echinodol (Manns; Hartmann, 1993) and echinoic acid (Tanaka et al., 1997) has also been discussed. The present study on further constituents was initiated because phytochemical knowledge about medicinally used plant material should be as broad as possible for a rational basis of its therapeutic usage.

\section{MATERIAL AND METHODS}

\section{Plant material}

Leaves of the plant were collected in September (spring time), 2001 in Ilhota, Santa Catarina State, Brazil and air-dried. A voucher specimen has been deposited at the herbarium of the Institute of Pharmaceutical Biology and Phytochemistry, Westfaelische Wilhelms-University Muenster, under the number PBMS 199.

\section{Extraction and fractionation}

The pulverized, air-dried leaves (1 kg) were submitted to an ultra-turrax extraction with $\mathrm{CH}_{2} \mathrm{Cl}_{2}$ to remove lipids. The residue (956 g) was exhaustively 
extracted with $\mathrm{EtOH} 70 \%(\mathrm{v} / \mathrm{v})$ to yield $202 \mathrm{~g}$ after lyophilization (total extract). The dry EtOH extract was dissolved in water and partitioned with EtOAc (A) and a second time after acidifying with $\mathrm{HCl}$ to $\mathrm{pH}$ of 2.0 (B). The EtOAc-fractions were evaporated (residue of A: 11.5 g; of B: $13.3 \mathrm{~g}$ ) and used for further purification.

\section{Chromatographic systems}

System 1: MPLC on $\mathrm{MCI}^{\circledR}$-gel CHP-20P (2.5 x $50 \mathrm{~cm})$, BESTA E100 pump, linear $\mathrm{MeOH} /$ water gradients; detection by TLC.

System 2: MLCCC (Ito Multilayer Coil Separator-Extractor, P.C., Inc. Potomac, MD/USA); column: 325 mL, I.D. 1.6 mm; Knauer HPLC Pump 64, rotation: $800 \mathrm{rpm}$, FWD; flow $1 \mathrm{~mL} / \mathrm{min}, 3 \mathrm{~mL} / \mathrm{tube}$; detection by TLC.

System 3: Preparative HPLC (Eurospher 100, RP-18, 7 mm, 20 x 250 mm; Waters multisolvent delivery system 600; Waters 490 Multiwavelength Detector; 1 = $280 \mathrm{~nm}$; mobile phase: $\mathrm{A}=$ Acetonitrile, $\mathrm{B}=0,1 \%$ TFA in Aqua Millipore ${ }^{\circledR}$.

System 4: MPLC column (RP-18, 18-32 mm, $100 \AA$ A, 36 x 500 mm); Besta Technik; BESTA E100 pump; linear $\mathrm{MeOH} /$ water gradients; detection by TLC.

TLC: Aluminum sheets with $0.2 \mathrm{~mm} \mathrm{SiO}_{2}$ (Merck, Darmstadt) developed with EtOAc/MeOH/ $/ \mathrm{H}_{2} \mathrm{O} /$ $\mathrm{HCOOH} \mathrm{100:10:10:1;} \mathrm{detection} \mathrm{at} 254$ and $360 \mathrm{~nm}$ and by Naturstoff reagent (diphenylboryloxyethylamine 1\% in $\mathrm{MeOH})$.

\section{Fractionation of the neutral EtOAc phase (A)}

The EtOAc phase A (11.5 g) was fractionated by MPLC on a polyamide column (25 x $500 \mathrm{~mm}$, packed with 75 g polyamide SC 6; Knauer HPLC Pump 64; Gradient: Aqua dem. 1.0 L, MeOH 25\% 0.5 L, MeOH 50\% $1.0 \mathrm{~L}, \mathrm{MeOH} 75 \%$ 0.5L, MeOH 100\% $1.0 \mathrm{~L}$; flow $7 \mathrm{~mL} / \mathrm{min}, 28 \mathrm{~mL} /$ tube) resulting in three fractions. Phenolic constituents were detected by TLC in fractions two and three.

Fraction two (tubes 57-106) was further fractionated by MPLC on system 1 with $\mathrm{MeOH} 10 \% \rightarrow$ 80\%, $2.0 \mathrm{~L}$ each; flow $8 \mathrm{~mL} / \mathrm{min} ; 24 \mathrm{~mL} /$ tube) to give five subfractions. Subfraction 3 (tubes 107-121) was further fractionated by system 2 with $n$-heptane/EtOAc/MeOH/ $\mathrm{H}_{2} \mathrm{O}$ (1:19:1:19), mobile phase was the upper phase. Pure isovitexin $(\mathbf{1 1}, 15 \mathrm{mg})$ was obtained from the eluate of 570 to $990 \mathrm{~mL}$.

Fraction three (tubes 107-136) was further fractionated using the system 1 with the same solvent as above with $7 \mathrm{~mL} / \mathrm{min}$ and $21 \mathrm{~mL} /$ tube) to give eight fractions. Fraction 7 (tubes 133-135) yielded pure swertisine (7, $58 \mathrm{mg})$; fraction 8 (136-148) was submitted to system 3 with a linear gradient of $20 \%$ to $23 \% \mathrm{~A}$ in $\mathrm{B}$ within $5 \mathrm{~min}$ followed by isocratic flow; $8 \mathrm{~mL} /$ min). The peak at 24 min yielded pure isoorientin-7,3'dimethylether (8, $5 \mathrm{mg})$.

\section{Fractionation of the acidic EtOAc phase (B)}

Phase B (13.3 g) was fractionated by system 2 with $\mathrm{CHCl}_{3} / \mathrm{MeOH} / \mathrm{H}_{2} \mathrm{O} / n-\mathrm{PrOH}$ (10:10:6:1, mobile phase was the upper phase) resulting in 9 fractions. Phenolic constituents were detected in fractions 1-5 and 9.

Fraction one of MLCCC (tubes 36-50) was submitted to system 4 with a linear gradient of $\mathrm{MeOH}$ $20 \%$ (0.8 L) $\rightarrow$ 80\% (1.0 L); flow $8.4 \mathrm{~mL} / \mathrm{min} ; 12.6 \mathrm{~mL} /$ tube) and gave three subfractions. Subfraction 1 (tubes 40-58) was submitted to system 1 with a linear gradient of $\mathrm{MeOH} 10 \% \rightarrow 80 \%, 1.25 \mathrm{~L}$ each; flow $6 \mathrm{~mL} / \mathrm{min}$; $24 \mathrm{~mL} /$ tube) yielding pure 2-O-caffeoyltartaric acid (2, caftaric acid, $152 \mathrm{mg}$; 204-282 mL). Subfraction 3 of MPLC (tubes 88-115) was submitted to system 1 with the same eluent system as for subfraction 1 yielding pure isoorientin (9, $81 \mathrm{mg}$; 522-552 mL) and swertiajaponin (10, $30 \mathrm{mg}$; 576-588 mL).

Fraction two of MLCCC (tubes 51-60) was fractionated by system 4 with a linear gradient of $\mathrm{MeOH}$ $10 \% \rightarrow 80 \%$, $1.5 \mathrm{~L}$ each; flow $7.2 \mathrm{~mL} / \mathrm{min} ; 22 \mathrm{~mL} / \mathrm{tube})$ and gave eight subfractions. Subfraction 1 (tubes 20-33) was subfractionated by system 1 using a linear gradient of $\mathrm{MeOH} 10 \% \rightarrow 80 \%, 1.0 \mathrm{~L}$ each; flow $7 \mathrm{~mL} / \mathrm{min} ; 14$ $\mathrm{mL} /$ tube) yielding pure trans-aconitic acid (1, $795 \mathrm{mg}$; $532-620 \mathrm{~mL}$ ). Subfraction 6 (tubes 73-93) was further fractionated by system 1 with a linear gradient of $\mathrm{MeOH}$ $10 \% \rightarrow 80 \%$, $1.5 \mathrm{~L}$ each; flow $7 \mathrm{~mL} / \mathrm{min} ; 28 \mathrm{~mL} /$ tube) yielding pure dicaffeoyltartaric acid (4, $370 \mathrm{mg}$, chichoric acid; 1944 - $2968 \mathrm{~mL}$ ). Subfractions 3 and 4 (tubes 6180) separated by system 1 with a linear gradient $\mathrm{MeOH}$ $10 \% \rightarrow 80 \%$, $1.5 \mathrm{~L}$ each; flow $6 \mathrm{~mL} / \mathrm{min} ; 18 \mathrm{~mL} /$ tube) and yielded pure 2-O-feruloyltartaric acid (3, $75 \mathrm{mg}$; 1124 - $1540 \mathrm{~mL}$ ).

Fraction five of MLCCC (tubes 81-110) was submitted to a Sephadex ${ }^{\circledR}$ LH-20 column $(2.3$ x $75 \mathrm{~cm})$, mobile phase EtOH 96\%, Flow 1.0 mL/min, 10 mL/tube; detection by TLC. The combined fraction in tubes 4965 was lyophilized and further fractionated by system 3 isocratically with $25 \% \mathrm{~A}$ in B at a flow of $4 \mathrm{~mL} / \mathrm{min}$. The peak eluting at 42 min was further purified by system 3 isocratically with $22 \% \mathrm{~A}$ in $\mathrm{B}$. The peak at 60 min yielded pure caffeoyl-feruloyltartaric acid (5, $50 \mathrm{mg})$.

Fraction nine of MLCCC (tubes 161-198) was fractionated by system 1 with a linear gradient of $\mathrm{MeOH}$ $10 \% \rightarrow 80 \%$, $1.5 \mathrm{~L}$ each; flow $6 \mathrm{~mL} / \mathrm{min} ; 18 \mathrm{~mL} / \mathrm{tube})$. The fraction eluting at $2142-2468 \mathrm{~mL}$ was lyophilized and was further purified by system 3 with a linear gradient of $20 \%$ A to $45 \%$ A in B within 20 min, flow $10 \mathrm{~mL} /$ min.). The peak at 22 min. yielded pure diferuloyltartaric acid (6, $13 \mathrm{mg})$.

Because the NMR data of compounds 5 and $\mathbf{6}$ 
are not fully reported in the literature, they are presented here as a complete set:

Caffeoyl-feruloyl-(2R,3R)-(+)-tartaric acid (5): $[\alpha]^{20}{ }_{\mathrm{D}}-214$ (c 0.055; $\left.\mathrm{MeOH}\right) ;{ }^{1} \mathrm{H}-\mathrm{NMR}$ (400 $\left.\mathrm{MHz}, \mathrm{CD}_{3} \mathrm{OD}, \delta_{\mathrm{H}} 3.35 \mathrm{ppm}\right): \delta 5.79(2 \mathrm{H}, \mathrm{s}, \mathrm{H}-2$ and $\mathrm{H}-3)$, 7.70/7.22 (2H, d, J 1.9/1.9 Hz, H-2' and $\left.\mathrm{H}-2^{\prime \prime}\right)$, 6.77/6.81 (2H, $d, J$ 8.2/8.2, $\mathrm{H}-5^{\prime}$ and $\left.\mathrm{H}-5^{\prime \prime}\right)$ ), 6.97/7.10 (2H, $d d, J$ 1.8/8.2; 1.8/8.2, H-6' and H-6"'), 7.64/7.70 (2H, $d, J$ 15.9/15.9, H-7' and H-7' '), 6.35/6.47 (2H, $d, J$ 15.9/15.9, H-8' and H-8"'), $3.88\left(\mathrm{OCH}_{3}\right) ;{ }^{13} \mathrm{C}-\mathrm{NMR}(100$ $\left.\mathrm{MHz}, \mathrm{CD}_{3} \mathrm{OD}, \delta_{\mathrm{C}} 49.3 \mathrm{ppm}\right): \delta 169.73$ (C-1 and C-4), 72.78 (C-2 and C-3), 127.60/127.60 (C-1' and C-1'”), 115.27/111.80 (C-2' and C-2'”), 146.89/149.43 (C-3' and C-3"'), 150.00/150.96 (C-4' and C-4"'), 116.62/116.58 (C-5' and C-5'), 123.49/124.62 (C-6" and C-6"'), 148.53/148.42 (C-7' and C-7'”), 113.76/114.17 (C-8' and C-8'),167.67/167.67 (C-9' and C-9'”), $56.69\left(\mathrm{OCH}_{3}\right)$; ESI-MS m/z 487.1 [M-H]', 975.0 [2M-H] $]^{-}$.

Di-feruloyl-(2R,3R)-(+)-tartaric acid (6): $[\alpha]^{20}{ }_{\mathrm{D}}$ -189 (c 0.013; MeOH); ${ }^{1} \mathrm{H}-\mathrm{NMR}\left(400 \mathrm{MHz}, \mathrm{CD}_{3} \mathrm{OD}, \delta_{\mathrm{H}}\right.$ $3.35 \mathrm{ppm}): \delta 5.85$ (2H, s, H-2 and $\mathrm{H}-3), 7.27$ (2H, $d, J$ $1.9 \mathrm{~Hz}, \mathrm{H}-2^{\prime}$ and $\left.\mathrm{H}-2^{\prime \prime}\right), 6.85$ (2H, $d, J$ 8.2, $\mathrm{H}-5^{\prime}$ and $\mathrm{H}-$ 5") 7.15 (2H, dd, J 1.9/8.2, H-6' and H-6") 7.75 (2H, $d, J$ 16.0, $\mathrm{H}-7^{\prime}$ and $\left.\mathrm{H}-7^{\prime \prime}\right), 6.51$ (2H, $d, J 16.0, \mathrm{H}-8^{\prime}$ and $\left.\mathrm{H}-8^{\prime \prime}\right), 3.93\left(\mathrm{OCH}_{3}\right) ;{ }^{13} \mathrm{C}-\mathrm{NMR}\left(100 \mathrm{MHz}, \mathrm{CD}_{3} \mathrm{OD}, \delta_{\mathrm{C}}\right.$ 49.3 ppm): $\delta 169.73$ (C-1 and C-4), 72.78 (C-2 and C-3), 127.62 (C-1' and C-1'”), 114.19 (C-2' and C-2'”), 148.41 (C-3' and C-3"'), 150.99 (C-4' and C-4"'), 116.59 (C-5' and C-5"'), 124.65 (C-6" and C-6"'), 149.46 (C-7' and C-7"'), 111.80 (C-8' and C-8'”), 167.65 (C-9' and C-9"'), $56.71\left(\mathrm{OCH}_{3}\right)$; ESI-MS m/z 501.0 [M-H]; 1002.9 [2M$\mathrm{H}]^{-}$.

\section{Chiral HPLC of tartaric acid}

To determine their absolute configuration, the tartaric acid derivatives were submitted to alkaline hydrolysis as described by Becker and Hsieh (1985) followed by chiral HPLC on a Chirex (D)-penicillamine column (4.6 x 50 mm, Phenomenex, Aschaffenburg, Germany) of thus obtained tartaric acid: isocratic system with $85 \%$ of a solution of $1.0 \mathrm{mM}$ copper (II) acetate and $0.05 \mathrm{M}$ ammonium acetate in water, $\mathrm{pH} 4.5$, and $15 \%$ isopropanol at $60{ }^{\circ} \mathrm{C}$. Detection was at $280 \mathrm{~nm}$. $\mathrm{T}_{\mathrm{R}}$ of $(2 S, 3 S)-\mathrm{D}-(-)$-tartaric acid was $1.3 \mathrm{~min}$. and of $(2 R, 3 R)-$ L-(+)-tartaric acid $8.7 \mathrm{~min}$.

\section{Quantitative HPLC}

Preparation of the extract: $2 \mathrm{~g}$ of the pulverized drug material was extracted with $30 \mathrm{~mL} \mathrm{CH}_{2} \mathrm{Cl}_{2}$ under ice cooling using an Ultra-Turrax (IKA, Staufen, Germany) to remove lipids (e.g. chlorophylls). The residue was extracted three times with $\mathrm{EtOH} \mathrm{70 \%} \mathrm{under} \mathrm{the} \mathrm{same}$ conditions. The collected EtOH phases were concentrated by rotation and finally freeze dried; the drug:extract residue was 4:1. For quantitative HPLC, $20.0 \mathrm{mg}$ of the extract were dissolved by sonication in $10.0 \mathrm{ml} \mathrm{MeOH} /$ Aqua Millipore (1:1) and filtered through a membrane filter. For quantification three extracts were prepared.

Calibration: The glucosylflavones were determined as isoorientin at $270 \mathrm{~nm}$ and the hydroxycinnamoyltartaric acids as caffeoyltartaric acid at $290 \mathrm{~nm}$ using methylcinnamate as an internal standard. Isolated isoorientin $\left(\mathrm{r}^{2}=0.9995\right)$ and caffeoyltartaric acid $\left(r^{2}=0.9984\right)$ ) were used for calibration. Factor for correction determined by HPLC at the wavelength chosen was 0.296 for the glucosylflavones, 0.265 for the hydroxycinnamoyltartaric acids with one chromophor $(2,3)$ and 1.297 for those with two chromophores (4 - 6). Trans-aconitic acid was determined at $220 \mathrm{~nm}$ using an external calibration curve $\left(r^{2}=0.9989\right)$. For intraday and interday precision three extracts were prepared at day 1 and at the following two days and quantified; the overall relative standard deviation was $\pm 3.65 \%$.

HPLC System: Waters Multisolvent Delivery System 600 with Waters 515 HPLC pump; Waters 990 Photodiode Array Detector; detection at 290, 280, 270

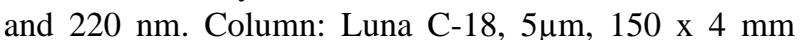
(Phenomenex, Aschaffenburg, Germany); mobile phase $\mathrm{A}=\mathrm{AcCN}, \mathrm{B}=0.1 \%$ TFA in Aqua Millipore ${ }^{\circledR}: 0-20 \mathrm{~min}$ $1 \%$ A : 99\% B; 20-45 min 20 : 80; 45-50 min 50 : 50; 50-55 min 100 : 0; 55-68 min 1 : 999; flow $0.6 \mathrm{~mL} / \mathrm{min}$. Assignment of peaks was done by their online UV spectra and after spiking them with the isolates $\mathbf{1}$ - $\mathbf{1 1}$ (Fig. 2).

\section{RESULTS AND DISCUSSION}

Fractionation of a defatted ethanol extract from the air-dried leaves was primarily conducted to obtain more information about the phenolic constituents of $E$. grandiflorus ssp. aureus. We isolated 2-O-caffeoyltartaric acid (2), 2-O-feruloyltartaric acid (3), cichoric acid (4), caffeoyl-feruloyl-tartaric acid (5), di-feruloyl-tartaric acid (6), swertisin (7), isoorientin-7,3'-dimethylether (8), isoorientin (9), swertiajaponin (10) and isovitexin (11) and the non-penolic trans-aconitic acid (1) (see Fig. 1). An analytical HPLC of a crude $70 \%$ ethanol extract is presented in Fig. 2; it shows the good separation of all major constituents 1 - 11. All except compounds 5 and 7 (Cechinel Filho, pers. comm.) were isolated for the first time from this plant material.

Structures were elucidated by spectroscopic methods $\left({ }^{1} \mathrm{H}\right.$ and ${ }^{13} \mathrm{C}$ NMR data, 1D- and 2D NMR experiments, ESI-MS and optical rotation) on comparison with data in the literature for flavone- $C$-glycosides (Davoust et al., 1980; Kato; Morita, 1990), tartaric acid derivatives (Singleton et al., 1978; Cheminat et al., 1988; Mulinacci et al., 2001), and trans-aconitic acid (Cai et al., 2001). The absolute configuration of the tartaric acid was determined by chiral HPLC to be the L-(+)- enantiomer (2R,3R-enantiomer).

Quantitative determination (Table 1) of the 
flavone-C-glycosides resulted in a total of $0.6 \%$ with swertiajaponin $(0.31 \% ; \mathbf{1 0})$ as the main compound. The hydroxycinnamoyltartaric acid esters sum up to $0.9 \%$ with cichoric acid (dicaffeoyltartaric acid, $0.42 \%$; 4 ) as the main representative; in any case, $(2 R, 3 R)$-tartaric acid is realized without any isomerization product. The highest yield with almost $1 \%$ was for trans-aconitic acid (1). However, it should be noticed that the quantitative data were obtained from one sample only.

Interestingly, only flavone 6-C-glycosides have been detected in the leaves of E. grandiflorus ssp. aureus; there was no indication of the accumulation of flavonols, O-glycosides or 8-C-glycosides. C-glycosilated flavones seem to be widely distributed in the Alismataceae family; they do not only occur in a close relative, E. muriaticus, but also in related genera such as Alisma, Baldellia, Damasonium and Sagittaria (Hegnauer, 1986). With respect to their tartaric acid esters, the leaves of $E$. grandiflorus ssp. aureus qualitatively and quantitatively resemble the herb of Echinacea purpurea (Soicke et al., 1988; Bauer et al., 1988).

trans-Aconitic acid occurs occasionally in higher plants although data on its distribution are rare. Nierhaus and Kinzel (1971) investigated 31 species of 27 families of higher plants for trans-aconitic acid as its TMS derivative by gas chromatography. Only species of the Ranunculaceae and Gramineae showed trans-aconitic acid as "main organic acid" or "in higher concentration" (absolute data are not given); all others showed "traces" only. The content of trans-aconitic acid in E. grandiflorus ssp. aureus with almost $1 \%$ is in a mean range of higher plants; thus the title plant does not belong to the accumulators of trans-aconitic acid which can reach up to $11 \%$ of dry weight as was shown for Asarum europaeum

(1) trans-aconitic acid<smiles>[R20]C(C(=O)O)C([R20])C(=O)O</smiles>

$\mathrm{R}_{1}=\mathrm{R}_{2}=\mathrm{H}:(2 R, 3 R)-(+)$-tartaric acid<smiles>CC(C)(C)C(=O)/C=C/c1ccc(O)c(O)c1</smiles>

caffeoyl<smiles>COc1cc(/C=C/C(=O)C(C)(C)C)ccc1O</smiles>

feruloyl
$\mathbf{R}_{1} \quad \mathbf{R}_{2}$

(2) 2-O-caffeoyl-(2R,3R)-(+)-tartaric acid

(3) 2- $O$-feruloyl- $(2 R, 3 R)-(+)$-tartaric acid

(4) dicaffeoyl- $(2 R, 3 R)-(+)$-tartaric acid

(5) caffeoyl-feruloyl- $(2 R, 3 R)-(+)$-tartaric acid

(6) diferuloyl- $(2 R, 3 R)-(+)$-tartaric acid

$\begin{array}{ll}\text { caffeoyl } & \mathrm{H} \\ \text { feruloyl } & \mathrm{H} \\ \text { caffeoyl } & \text { caffeoyl } \\ \text { caffeoyl } & \text { feruloyl } \\ \text { feruloyl } & \text { feruloyl }\end{array}$
(7) swertisin
$\mathbf{R}_{1} \mathbf{R}_{2}$
(8) isoorientin-7,3'-dimethylether
(9) isoorientin
(10) swertiajaponin
(11) isovitexin

$\begin{array}{ll}\mathbf{R}_{1} & \mathbf{R}_{2} \\ & \\ \text { OMe } & \mathrm{H} \\ \text { OMe } & \mathrm{OMe} \\ \mathrm{OH} & \mathrm{OH} \\ \mathrm{OMe} & \mathrm{OH} \\ \mathrm{OH} & \mathrm{H}\end{array}$<smiles>[R2]c1cc(-c2cc(=O)c3c(O)c([I+]4OC[C@H](O)[C@H](O)[C@H]4O)c([R])cc3o2)ccc1O</smiles>

Figure 1. Compounds isolated from the leaves of E. grandiflorus ssp. aureus. 


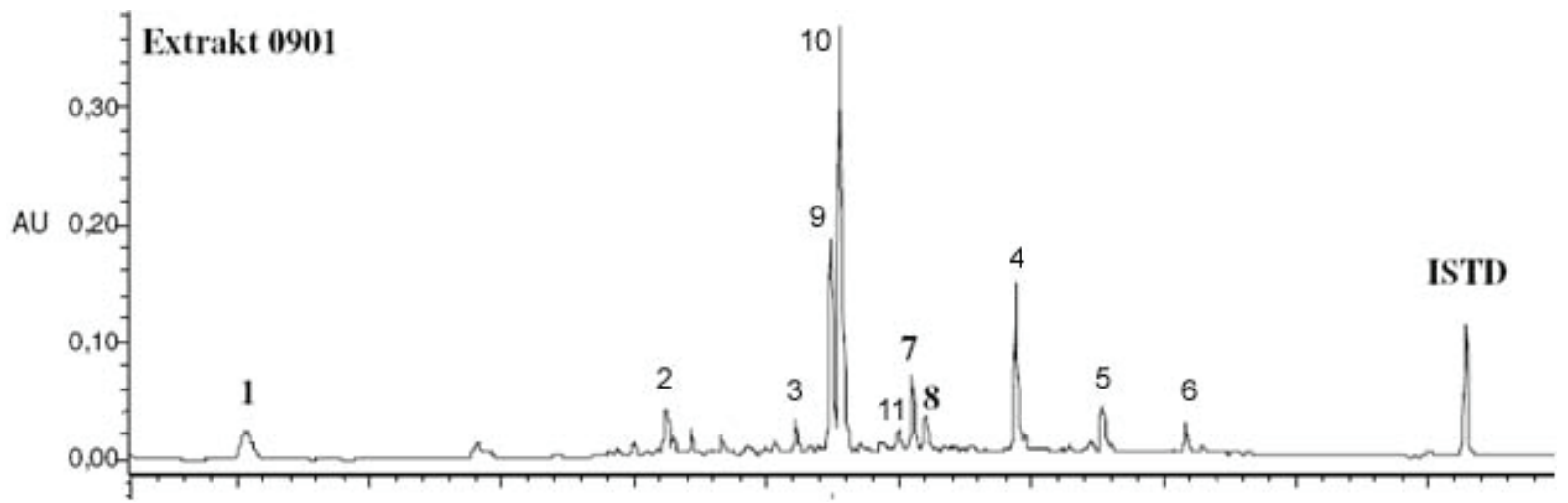

Figure 2. HPLC of the $70 \%$ ethanol extract for quantification from the dried leaves of E. grandiflorus ssp. aureus; detection shown here: $270 \mathrm{~nm}$; chromatographic conditions see 2.4. Numbering of peaks as in Figure 1; ISTD = Internal standard (methylcinnamate).

Table 1. Contents of compounds $\mathbf{1}$ - $\mathbf{1 1}$ in \% of the crude dried leaves of E. grandiflorus ssp. aureus harvested in Sept. $2001 . \mathbf{1}$ was determined using an external standard curve; $\mathbf{2}$ - $\mathbf{6}$ were determined as caffeoyltartaric acid with a correction factor used for the disubstituted hydroxycinnamoyltartaric acids; 7 - 11 were determined as isoorientin. Mean values and their deviation are from three independently processed samples.

\begin{tabular}{lccc}
\hline trans-Aconitic acid & $\mathbf{( 1 )}$ & $0.977 \pm 0.028$ \\
2- $O$-Caffeoyltartaric acid & $\mathbf{( 2 )}$ & $0.133 \pm 0.009$ \\
2- $O$-Feruloyltartaric acid & $\mathbf{( 3 )}$ & $0.112 \pm 0.004$ & \\
Dicaffeoyltartaric acid & $\mathbf{( 4 )}$ & $0.423 \pm 0.043$ & Sum 0.90 \\
Caffeoylferuloyltartaric acid & $\mathbf{( 5 )}$ & $0.130 \pm 0.011$ & \\
Diferuloyltartaric acid & $\mathbf{( 6 )}$ & $0.105 \pm 0.007$ & Sum 0.59 \\
Swertisin & $\mathbf{( 7 )}$ & $0.033 \pm 0.003$ & $0.154 \pm 0.030$ \\
Isoorientin-7,3'-dimethylether & $\mathbf{( 8 )}$ & $0.308 \pm 0.052$ & \\
Isoorientin & $\mathbf{( 9 )}$ & $0.033 \pm 0.005$ & \\
Swertiajaponin & $\mathbf{( 1 0 )}$ & & \\
Isovitexin & $\mathbf{( 1 1 )}$ & & \\
\hline
\end{tabular}

(Krogh, 1971). Bohman et al. (1983) found trans-aconitic acid from cereal pastures with up to $5 \%$ responsible for tetany in cattle; the toxic product is not compound $\mathbf{1}$ itself but tricarballylic acid that is produced by reduction of $\mathbf{1}$ by the microflora in the rumen (Schwartz et al., 1988). Grunes (1967) argued that trans-aconitic acid higher than $1 \%$ already may cause tetany in the animals; thus the leaves of $E$. grandiflorus ssp. aureus may be toxic for ruminants. Compound $\mathbf{1}$ also shows allelopathic (Voll et al., 2005) and antifeeding activity (Nagata; Hayakawat, 1998); thus the amount of almost $1 \%$ trans-aconitic acid in E. grandiflorus ssp. aureus may serve for its chemical defense. The Material Safety Data Sheet (https://fscimage. fishersci.com/msds/73684.htm) informs that pure transaconitic acid in man causes eye, skin and gastrointestinal irritation; it also states that no toxicological information was found; the leaves of E. grandiflorus ssp. aureus can therefore be regarded as non-toxic for man. On the other hand, cis-aconitic acid, which is a metabolic product of the citric acid cycle, inhibits carcinogenesis induced by 3,4-benzopyrene in experimental animals (Kallistratos; Kallistratos, 1976), but trans-aconitic acid has not been investigated.

\section{ACKNOWLEDGMENTS}

The authors would like to thank Prof. Dr. V. Cechinel Filho (UNIVALI, Itajaí-SC, Brazil) for collecting the plant material. We are grateful to M.-T. Heim, Dr. H. Lahl, and Dr. K. Bergander for recording the NMR spectra, and T. Meiners and Dr. H. Luftmann for performing the ESI-MS experiments (University of Münster, Germany). Thanks are due to Prof. Dr. V. Butterweck, Gainesville (Florida), for linguistic advice.

\section{REFERENCES}

Agra MF, França PF, Barbosa-Filho JM 2007. Synopsis of the plants known as medicinal and poisonous in Northeast of Brazil. Rev Bras Farmacogn 17: 114-140.

Bauer R, Reimiger P, Wagner H 1988. Echinacea. Dtsch Apoth Ztg 128: 174-180.

Becker H, Hsieh WC 1985. Chicoree-säure und deren derivate aus Echinacea-Arten. Z Naturforsch 40c: 585-587.

Bohman VR, Horn FP, Stewart BA, Mathers AC, Grunes DL 1983. Wheat pasture poisoning I. An evaluation of cereal pastures as related to tetany in beef cows. $J$ Animal Sci 57: 1352-1363.

Cai H, Strouse J, Sumlao D, Jung ME, Clarke S 2001. Distinct reaction catalysed by bacterial and yeast trans-aconite 
methyltransferases. Biochem 40: 2210-2219.

Cheminat A, Zawatzky R, Becker H, Brouillard R 1988. Caffeoyl conjugates from Echinacea species: Structures and biological activity. Phytochemistry 27: 2787-2794.

Davoust D, Massias M, Molho D 1980. ${ }^{13} \mathrm{C}$ NMR investigation of flavonoid C-ß-D-glucosides. Detection of a conformational equilibrium. Org Magn Res 13: 218219.

De Souza GC, Haas AP, von Poser GL, Schapoval EES, Elisabetsky E 2004. Ethnopharmacological studies of antimicrobial remedies in the South of Brazil. $J$ Ethnopharmacol 90: 135-143.

Dutra RC, Tavares CZ, Ferraz SO, Sousa OV, Pimenta DS 2006. Investigação das atividades analgésica e antiinflamatória do extrato metanólico dos rizomas de Echinodorus grandiflorus. Rev Bras Farmacogn 16: 469-474.

Grunes DL 1967. Cornell Nutrition Conference for Feed Manufacturers. Buffalo NY p.105. Ithaca NY: Cornell Agric. Expt. Station.

Hegnauer R 1986. Chemotaxonomie der Pflanzen, Vol. VII. Basel: Birkhäuser.

Kallistratos G, Kallistratos U 1976. 3,4-Benzopyrene carcinogenesis and its inhibition by natural and synthetic compounds. Folia Biochim Biol Graeca 13: 1-10.

Kato T, Morita Y 1990. C-Glycosylflavones with acetyl substitution from Rumex acetosa L. Chem Pharm Bull 38: 2277-2280.

Krogh A 1971. Content of trans-aconitic acid in Asarum europaeum determined by means of a chromatogram spectrometer. Act Chim Scand 25: 1495-1496.

Manns D, Hartmann R 1993. Echinodol: A new cembran derivative from Echinodorus grandiflorus. Planta Med 59: 465-466.

Mulinacci N, Innocenti M, Gallori S, Romani A, la Marca G, Vincieri FF 2001. Optimization of the chromatographic determination of polyphenols in the aerial parts of Cichorium intybus L. Chromatographia 54: 455-451.

Nagata T, Hayakawat T 1998. Antifeeding activity of aconitic acids and oxalic acid on brown planthopper, Niaparvata lugens (Satl) and green rice leafhopper, Nephotettix cincticeps (Uhler). Jap J Appl Entomol Zool 42: 115-121.

Nierhaus D, Kinzel H 1971. Comparative investigations on organic acids in leaves of higher plants. $Z$ Pflanzenphysiol 64: 107-123.

Schwartz R, Topley M, Russell JB 1988. Effect of tricarballylic acid, a nonmetabolizable rumen fermentation product of trans-aconitic acid in magnesium, calcium and zinc utilization of rats. J Nutr 118: 183-188.

Singleton VL, Timberlake CF, Lea AGH 1978. The phenolic cinnamates of white grape and wine. J Sci Food Agric 29: 403-410.

Soicke H, Al-Hassan G, Görler K 1988. Weitere Kaffeesäurederivate aus Echinacea purpurea. Planta Med 54: 175-176.

Tanaka CMA, Saragiotto MH, Zukerman-Schpector J, Marsaioli AJ 1997. A cembrane from Echinodorus grandiflorus. Phytochemistry 44: 1547-1549.

Voll E, Voll CE, Filho RV 2005. Allelopathic effect of aconitic acid on wild poinsettia (Euphorbia heterophylla) and morningglory (Ipomoea grandiflora). Environ Sci 